\title{
The site of disruption of the bronchial epithelium in asthmatic and non-asthmatic subjects
}

\author{
S Montefort, J A Roberts, R Beasley, S T Holgate, W R Roche
}

\begin{abstract}
Background Attention has recently been focused on the basal cells of the tracheobronchial epithelium as the mechanism of anchorage of the tall columnar cells, which themselves do not appear to form hemidesmosomes with the basement membrane of the epithelium. Residual basal cells have been described as remaining attached to the basement membrane after epithelial denudation. This led this group to formulate the hypothesis that there may be a potential plane of cleavage between the basal cells and the overlying columnar cell layer within the bronchial epithelium, which becomes disrupted in asthma.
\end{abstract}

Methods Bronchoalveolar lavage samples were obtained during bronchoscopy from eight patients with atopic asthma and four normal controls. Ultrathin sections of lavage cell pellets were examined by electron microscopy and the number of columnar and basal cells found in each epithelial cell cluster was counted. Cytocentrifuge preparations of the lavage samples from the same subjects were also examined for free epithelial cells and epithelial cell clusters.

Results Electron microscopic examination of the cell pellets showed that basal cells were present in very small numbers in the epithelial clusters in all subjects (mean 0.03 (SE 0.02)/cluster) and the ratio of columnar cells to basal cells was far greater than was encountered in the intact bronchial epithelium (167 $v 4)$. The cytocentrifuge preparations showed an increased number of epithelial cell clusters and epithelial cells in the asthmatic patients. Although these clusters were similar in size in the two groups of subjects $(6.3 \vee 5 \cdot 1$ cells/cluster $)$ the ratio of free epithelial cells to cells within the cluster was higher in the non-asthmatic subjects.

Conclusions It is proposed that shedding of epithelial cells occurs along a suprabasal plane and that there is a potential plane of cleavage between the suprabasal and the basal cell layers, which might be more vulnerable to the various insults.

Shedding of the bronchial epithelium has been long associated with bronchial asthma, through necropsy ${ }^{1}$ and sputum cytology studies $^{2}$ and, more recently, bronchial biopsy. ${ }^{3}$ These studies in the living patient have allowed the investigation of the associations of this phenomenon and recent studies have indicated that correlations exist between bronchial hyperresponsiveness and the epithelial cell loss recovered by bronchoalveolar lavage. ${ }^{4}$ Many hypotheses have been proposed to explain this association, including exposure of sensory nerve endings leading to reflex secretion of bronchoconstrictor neuropeptides, ${ }^{5}$ loss of epithelial relaxant factors, ${ }^{6}$ and elaboration of endothelin, ${ }^{7}$ all of which might cause bronchial smooth muscle contraction. Alternatively, the epithelial cell damage might be merely a bystander effect of bronchial inflammation. Epithelial cell adhesion, however, is generally held to be essential for maintaining normal bronchial homeostasis and destruction of the cohesive mechanisms to have an important role in bronchial asthma. ${ }^{8}$

Various cell adhesion mechanisms are used in the maintenance of the bronchial epithelium, akin to those for other epithelia. The bronchial epithelial cell layer is sealed by apical tight junctions, while gap junctions and desmosomes and other cell adhesion molecules allow adhesion and communication between the epithelial cells. Contact with the basement membrane is maintained by hemidesmosomes, focal contacts, and specific receptors for components of the extracellular matrix. ${ }^{9-11}$ Studies of tracheal epithelium have shown that the few ciliated and secretory columnar epithelial cells that span the whole epithelial thickness do not form junctional attachments with the underlying epithelial basement membrane. Rather, these cells appear to be attached via desmosomes on their basolateral surfaces to basal cells, which themselves then form hemidesmosomal contacts with the basement membrane. ${ }^{12}$ Thus this respiratory epithelium is a truly stratified complex epithelium. Comparative studies in the range of mammalian species have lent support to this model; as the height of the tracheal epithelium increases there is a proportionate increase in the number of basal cells and in their content of intracellular filaments, suggesting that the basal cells provide the necessary anchorage for the overlying columnar cells. ${ }^{12-17}$

A study of the bronchial epithelium in asthma, based on biopsy specimens obtained via the rigid bronchoscope, has shown partial epithelial cell denudation with residual basal cells remaining attached to the underlying
Southampton General

Hospital,

SO9 4XY

Reprint requests to:

Dr S Montefort

Accepted February 1992 
basement membrane. ${ }^{3}$ Similarly, smoke damage of ovine bronchial epithelium results in shedding of columnar epithelial cells, again leaving the basal cells still attached to the basement membrane. ${ }^{18}$ Similar findings have been reported in fatal bronchial asthma. ${ }^{19}$ Taken together, these findings indicate a potential plane of cleavage in the bronchial epithelium between the basal cells and the overlying columnar epithelial cells. This may be due to a difference in the cell adhesion mechanisms at this site or may reflect directed cell injury inflicted by eosinophils, smoke, etc. Either mechanism might result in the shedding of columnar epithelial cells into the bronchial lumen.

To investigate the potential site of epithelial damage in asthma we have examined bronchial lavage specimens, by light and electron microscopy, to determine the extent and pattern of bronchial epithelial cell shedding and the ratio of columnar cells to basal cells.

\section{Methods}

SUBJECTS

We studied eight male atopic asthmatic volunteers (mean (SE) age 21.9 (0.81) years) and four symptomless normal, healthy male control subjects $(32.8(3.22)$ years) (table). The inclusion criteria for the asthmatic subjects were: minimum baseline $\mathrm{FEV}_{1} 70 \%$ predicted for subject's age and height (mean $98.1 \%$ ), a concentration of histamine causing a $20 \%$ fall in $\mathrm{FEV}_{1}$ from baseline $\left(\mathrm{PC}_{20}\right)$ below 8 (geometric mean 0.91 , range $0.03-7.2$ ) $\mathrm{mg} / \mathrm{ml}$, and a positive skin weal response to one or more of the common allergens Dermatophagoides pteronyssinus, mixed grass pollen, and cat dander (Bencard, Brentford, Middlesex). The normal controls had no past history of asthma, a baseline of $F E V_{1}$ greater than $70 \%$ predicted, and $a \mathrm{PC}_{20}$ of more than 8 (geometric mean $43 \cdot 12$, range $16-64) \mathrm{mg} / \mathrm{ml}$, and were nonatopic. All volunteers were non-smokers and did not have any history of a respiratory tract infection within the eight weeks before the bronchoscopy.
The study, which conformed to the Declaration of Helsinki, was approved by the combined Southampton hospitals and the university ethical subcommittee. Informed consent was obtained from all subjects.

\section{STUDY DESIGN}

Subjects attended the laboratory on two occasions separated by five days. On the first visit skinprick testing with common allergens and measurements of $\mathrm{FEV}_{1}$ (best of three attempts) and $\mathrm{PC}_{20}$ were performed by a technique adapted from that of Chai et $a l,{ }^{20}$ as described previously. ${ }^{21}$

On the second visit fibreoptic bronchoscopy was undertaken provided that $\mathrm{FEV}_{1}$ was above $70 \%$ predicted. Bronchoscopy was carried out according to the guidelines outlined by the American Thoracic Society. ${ }^{22}$ The bronchoscopy procedure has been described by us previously. ${ }^{23}$ The bronchoscope was wedged in the posterior division of the right upper lobe. Fifty millilitres of warm sterile $0.9 \%$ sodium chloride were instilled into the right upper lobe segment, after which the subject was instructed to take two breaths from residual volume to total lung capacity. The fluid was then aspirated through the suction channel of the bronchoscope with $50 \mathrm{~mm} \mathrm{Hg}$ negative pressure, collected in chilled suction traps, and held at $4^{\circ} \mathrm{C}$. On completion of the procedure subjects were observed for three hours and further nebulised salbutamol was given. Each specimen was assigned an alphanumerical code and the clinical and physiological data were not revealed to the observers interpreting the specimens.

\section{SAMPLE PROCESSING}

The lavage fluid was homogenised by gentle shaking, the volume measured, and 200 cells counted in a haemocytometer with the use of phase contrast optics. The lavage was not sieved through gauze so as to prevent loss of epithelial cell clusters. May-GrünwaldGiemsa stained cytocentrifuge preparations (Cytospin, Shandon Southern, Runcorn) were

Characteristics of asthmatic and control subjects

\begin{tabular}{|c|c|c|c|}
\hline & \multicolumn{3}{|l|}{ Subjects } \\
\hline & Normal control & Asthmatic & \\
\hline $\begin{array}{l}\text { Age (years) } \\
\mathrm{FEV}_{1}(\% \text { predicted }) \\
\left.\mathrm{PC}_{20} \text { (mg/ml, geometric mean }\right)\end{array}$ & $\begin{array}{c}\text { Mean (range) } \\
32 \cdot 7(27-42) \\
104 \cdot 7(91-122) \\
42 \cdot 9(16-64)\end{array}$ & $\begin{array}{l}\text { Mean (range) } \\
21 \cdot 9(19-28) \\
98 \cdot 1(73-120) \\
0 \cdot 91(0 \cdot 03-7 \cdot 2)\end{array}$ & \\
\hline \multicolumn{4}{|c|}{ Data from electron microscopic examination of clusters in lavage fluid } \\
\hline & Median (range) & Median (range) & \\
\hline $\begin{array}{l}\text { Number of: } \\
\text { Epithelial cell clusters/subject } \\
\text { Cells/cluster } \\
\text { Basal cells/cluster }\end{array}$ & $\begin{array}{l}4 \cdot 5(3-9) \\
3 \cdot 7(2 \cdot 8-6) \\
0\end{array}$ & $\begin{array}{l}8(1-22) \\
4 \cdot 5(3-11 \cdot 7) \\
0(0-0 \cdot 2)\end{array}$ & \\
\hline \multicolumn{4}{|c|}{ Data from examination of cytocentrifuge preparations } \\
\hline Number of: & Median (range). & Median (range) & $p$ \\
\hline $\begin{array}{l}\text { Total epithelial cells/subject }(\times 1000 / \mathrm{ml} \text { ) } \\
\text { Clusters/subject/ml } \\
\text { Cells/cluster } \\
\text { Ratio of free epithelial cells to cluster cells* }\end{array}$ & $\begin{array}{l}11 \cdot 5(3 \cdot 4-32 \cdot 8) \\
44(17-109) \\
4 \cdot 2(3 \cdot 8-8 \cdot 3) \\
5 \cdot 3(3 \cdot 6-6 \cdot 9)\end{array}$ & $\begin{array}{l}47 \cdot 2(11 \cdot 5-209 \cdot 6) \\
367(49-713) \\
5 \cdot 9(3 \cdot 7-10 \cdot 3) \\
2 \cdot 7(1 \cdot 1-5 \cdot 3)\end{array}$ & $\begin{array}{l}0.048 \\
0.028 \\
\text { NS } \\
0.02\end{array}$ \\
\hline
\end{tabular}

^Ratio of the number of free epithelial cells counted until 10 clusters seen to the number of cells in those 10 clusters. $\mathrm{FEV}_{1}$ - forced expiratory volume in one second; $\mathrm{PC}_{20}$-provocative concentration of histamine causing a $20 \%$ fall in $\mathrm{FEV}_{1}$. 
prepared and used for differential counting, and also for counting free epithelial cells and epithelial cell clusters as described below.

The cells from the remainder of the lavage were pelleted at $250 \mathrm{~g}$ for five minutes. ${ }^{24}$ The cell pellets were then fixed in $2.5 \%$ glutaraldehyde for two hours and then washed in $0.1 \mathrm{M}$ caccodylate-sucrose buffer overnight. The next day the pellets were post-fixed in $2 \%$ osmium tetroxide in caccodylate buffer for 20 minutes, rinsed in millipored double distilled water, stained in $2 \%$ uranyl acetate, and dehydrated through graded alcohols. The sections were then cleared in Histosol for 20 minutes, infiltrated with $50: 50 \mathrm{Histosol} / \mathrm{Spurr}$ resin for 30 minutes, and finally infiltrated in $100 \%$ Spurr overnight. The cells were embedded in Spurr in a small tube, spun, and polymerised at $60^{\circ} \mathrm{C}$ for 16 hours. Thin sections were mounted on uncoated copper grids and were examined with a Hitachi H7000 microscope (Hitachi, Tokyo).

\section{ASSESSMENT OF EPITHELIAL CELL CLUSTERS}

The electronmicroscopy grids were examined by one observer (SM) at a magnification of $\times 1000$. Micrographs were prepared of each epithelial cell cluster representing two epithelial cells or more identified in each entire section. Single epithelial cells were not included. The electron micrographs were then examined by a separate observer (WRR) without knowledge of the source of the specimen to identify any basal cells still attached to the epithelial clusters. The basal cells, when present, were identified as small pyramidal cells that do not reach the luminal surface of the epithelial cluster with scanty, moderately electron dense cytoplasm. ${ }^{25}$ The number of columnar cells in the clusters was also counted.

The cytocentrifuge preparation sections were examined by the same blinded observer

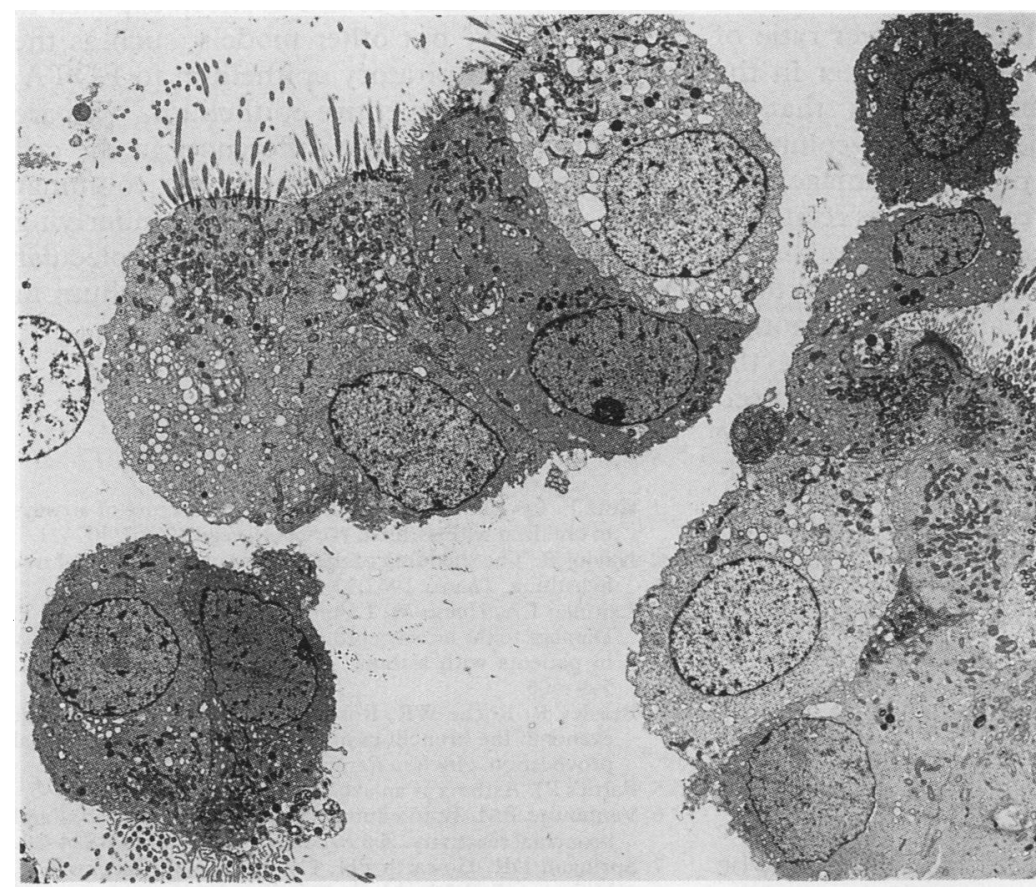

Figure 1 Some of the epithelial clusters seen in bronchoalveolar lavage pellets, made up solely of columnar cells. with a Leitz Ortholux 2 microscope (Ernst Leitz, Wetzler, Germany). The epithelial cells in the cytocentifuge sample were expressed as a percentage of the total nucleated cell count and this was corrected to yield epithelial cells per millilitre. The May-Grünwald-Giesma cytospin preparations were then re-examined and the number of free epithelial cells and clusters were counted until 10 epithelial cell clusters had been observed. The number of cells forming the 10 clusters was also counted. The total number of clusters per millilitre of lavage sample was then calculated.

\section{DATA ANALYSIS}

The difference in number of epithelial cells, clusters/ml of lavage fluid, composition of the clusters, and ratio of free epithelial cells and cells in the clusters in the asthmatic and control groups as seen in the cytocentrifuge preparations were compared by the Mann-Whitney U test.

\section{Results}

Electron microscopic examination of the cell pellets from both groups of subjects (table) showed that most epithelial cell clusters were devoid of basal cells (fig 1), and except for one subject there was no more than one basal cell adherent to any cluster. The ratio between the number of columnar cells and basal cells per cluster was significantly different from the ratio of these cells in intact bronchial epithelium167 columnar cells: 1 basal cell in clusters as opposed to about 4 columnar cells to 1 basal cell observed in intact epithelium. ${ }^{26}$ The inferior aspect of each cluster was uneven as if from an "unzipping" of the columnar epithelium from the basal cell layer. We also noted that the columnar cells in the clumps were generally intact, confirming that the break from the basal cell layer occurred at the cell to cell junction and was not due to tearing of the cytoplasmic continuity of the cell itself.

We examined the cytocentrifuge samples as these were more reliable for measuring the numbers of free epithelial cells and epithelial cell clusters (Table). As we have reported previously, ${ }^{4}$ the number of total epithelial cells both free and in clusters was significantly higher in the asthmatic subjects than in the normal controls $(p=0.048)$ and there was an inverse correlation with the $\log \mathrm{PC}_{20}$ histamine value. The clusters were also significantly more numerous in the lavage fluid from the asthmatic subjects $(p=0.028)$, though the mean sizes of the clusters in the two groups of subjects were similar (6.3 $v 5 \cdot 1$ cells/cluster, NS). There was no correlation between the number of clusters/ $\mathrm{ml}$ of lavage fluid and the $\mathrm{PC}_{20}$ histamine of the individual asthmatic subjects. Proportionally more of the epithelial cells shed into the lavage fluid from the asthmatic subjects were as clusters rather than single cells. The ratio between free epithelial cells counted until 10 clusters were seen and the cells within those 10 clusters was significantly different in the two groups $(p=0.02)$. 
Figure 2 Wide plane of cleavage seen between basal cell layer and overlying columnar cells (arrows) in a bronchial biopsy specimen from $a$ patient with asthma.

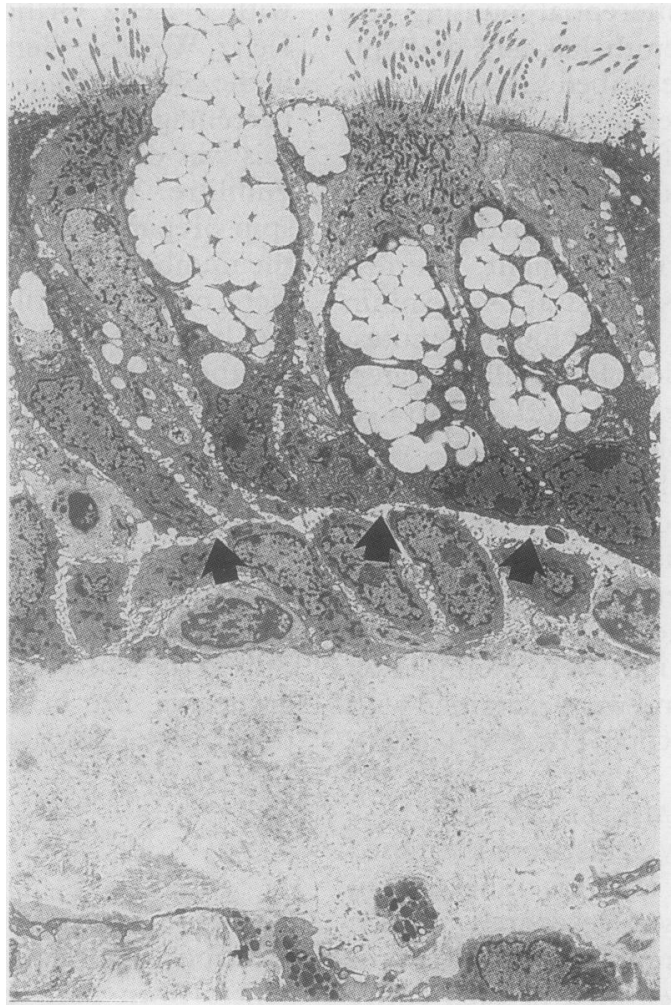

\section{Discussion}

We have shown that in bronchoalveolar lavage fluid from both asthmatic and normal subjects the epithelial cell clusters contain few basal cells. This disruption of the epithelium appears to occur at the suprabasal-basal cell layer junction. This supports our hypothesis that bronchial epithelial shedding occurs in a suprabasal plane, probably as a result of a weak line of adhesion along this plane. The excess of free epithelial cells and clusters in the lavage fluid from asthmatic subjects points to the propensity of this site for injury in asthma. Although there was no significant difference in the size of clusters, we found a lower ratio of free epithelial cells to cells per cluster in the asthmatic subjects. This suggests that in patients with asthma the basal cell-columnar cell attachment is more prone to damage than the columnar-columnar cell bond, as relatively more columnar cells are shed in clusters than in non-asthmatic subjects, where cells seem to be shed more in an individual manner. Another reasons for this finding could be that the epithelial insults found in asthma are focused on the presumably more vulnerable adhesive mechanisms at this site, thus leading to shedding of a whole cluster of the overlying columnar cells, which are still stuck together. Figure 2 shows this wide plane of potential cleavage between the basal and suprabasal cell layers in a bronchial biopsy specimen taken from an asthmatic patient. It is still unknown why the basal cell-basement membrane adhesion seems to be more resistant to damage, but this might be due to adhesive mechanisms and their components (such as hemidesmosomes), which are exclusively found at this site and which may be more resistant to whatever noxious injury is causing the columnar cell layer to be shed.
The basal cell used to be thought of as a progenitor cell in the bronchial epithelium but this function has now been attributed to the non-ciliated columnar cell. ${ }^{27}$ More recently, the basal cell has been regarded by some as being important in the adhesion of the bronchial epithelium to the underlying basement membrane. ${ }^{12-14}$ The lack of columnar cell hemidesmosomes would require some other mode of adherence to their underlying basement membrane. ${ }^{25}$ This may depend on desmosomal attachment to basal cells, which in turn adhere to the basement membrane via basal hemidesmosomes.

Extrapolation from these findings would suggest that the site of adhesion between the columnar cells and the underlying basal cells may be an important target for cell damage in the bronchial epithelium. Exposure of guinea pig respiratory epithelium to eosinophil major basic protein has been shown to induce detachment of the columnar cells from the basal cell layer while the basal cells maintain their contact with the basement membrane. Higher concentrations of major basic protein are required to induce detachment of the basal cells. ${ }^{28}$ This suggests that the basal cell attachment to the basement membrane is more resistant to attack by eosinophils than the adhesive mechanisms that attach the columnar cells to these basal cells. This is in keeping with our findings that the epithelial cell clusters in lavage fluid do not contain many basal cells. It would also appear that the adherence between the neighbouring columnar cells is more robust than that between the columnar cells and basal cells, as the columnar cell clusters of up to 30 cells remain intact after being shed into the bronchial lumen.

We propose that there is a potential plane of cleavage between the columnar cells and basal cells that may be opened by toxic substances, such as eosinophil major basic protein. This has been previously found in sheep exposed to cotton smoke $\mathrm{e}^{18}$ but other models, such as the exposure of respiratory epithelium to EDTA, have disrupted the entire epithelium. ${ }^{17}$ We are currently exploring the differences in the cell adhesion mechanisms between the columnar cells, the basal cells, and the underlying basement membrane to define the molecular basis of the vulnerability of the epithelium in bronchial asthma.

SM is a Commonwealth scholar.

1 Cutz F, Levison H, Cooper DM. Ultrastructure of airways in children with asthma. Histopathology 1978;2:407-21.

2 Naylor B. The shedding of the mucosa of the bronchial tree in asthma. Thorax 1962;17:69-72.

3 Laitinen LA, Heino M, Laitenen A, Kava T, Hauhtela T. Damage to the airway epithelium and bronchial reactivity in patients with asthma. Am Rev Respir Dis 1985;131: 599-606.

4 Beasley R, Roche WR, Roberts JA, Holgate ST. Cellular events in the bronchi in mild asthma and after bronchial provocation. Am Rev Respir Dis 1989;139:806-17.

5 Barnes PJ. Asthma as an axon reflex. Lancet 1986;ii:242-5.

6 Vanhoutte PM. Epithelium-derived relaxing factor(s) and bronchial reactivity. Am Rev Respir Dis 1988;138:S24-30.

7 Springall DR, Howarth PH, Counihan H, Djukanovic R, Holgate ST, Polak JM. Endothelium immunoreactivity of airway epithelium in asthmatic patients. Lancet 1991 337:697-701. 
8 Hogg JC, Eggleton PA. Is asthma an epithelial disease? [editorial]. Am Rev Respir Dis 1984;129:207-8.

9 Garrod DR. Desmosomes, cell adhesion molecules and the adhesive properties of cells in tissues. J Cell Sci 1986;suppl 4:221-37.

10 Bucca EC, Rolla G, Scappatici E, Cantino D. A freezefracture study of human bronchial epithelium in normal, bronchitic and asthmatic subjects. J Submicrosc Cytol Pathol 1988;20:509-17.

11 Yurchenko PD, Schittny JC. Molecular architecture of basement membrane. FASEB J 1990;4:1577-90

12 Evans MJ, Plopper CG. The role of basal cells in adhesion of columnar epithelium to airway basement membrane. $A m$ Rev Respir Dis 1989;138:481-3.

13 Evans MJ, Cox RA, Shami SG, Wilson B, Plopper CG. The role of the basal cells in attachment of columnar cells to the basal lamina of the trachea. Am Rev Respir Cell Biol 1989;1:463-9.

14 Evans MJ, Cox RA, Shami SG, Plopper CG. Junctional adhesion mechanisms in airway basal cells. Am Rev Respir Cell Mol Biol 1990;3:341-7.

15 Christensen JG, Breuer R, Hornstra J, Lucey EC, Snider GL. The ultrastructure of hamster bronchial epithelium. Exp Lung Res 1987;13:253-77.

16 Kawanami D, Ferranis VJ, Crystal RG. Anchoring fibrils in the normal canine respiratory system. Am Rev Respir Dis 1979;120:585-611.

17 Tandler B, Sherman J, Boat TF. EDTA-mediated separation of cat tracheal lining epithelium. Am Rev Respir Dis 1981:124:469-75.

18 Abdi S, Evan MJ, Cox RA, Lubbesmeyer H, Herndon D, Traber DL. Inhalation injury to tracheal epithelium in an ovine model of cotton smoke exposure-early phase ( 30 min). Am Rev Respir Dis 1990;142:1436-9.

19 Dunnill MS. The pathology of asthma, with specific reference to changes in the bronchial mucosa. $J$ Clin Pathol 1960;13:27-33.

20 Chai H, Fan RS, Frolish LA, Mathison DA, Mclean JA, Rosenthal RR, et al. Standardisation of bronchial inhalation challenge procedures. J Allergy Clin Immunol 1975; 56:232-7.

21 Rafferty $\mathrm{P}$, Holgate ST. Terfanidine(Seldane) is a potent and selective histamine $\mathrm{H}_{1}$ receptor antagonist in asthmatic airways. Am Rev Respir Dis 1987;135:181-4.

22 Workshop on the investigative use of fibreoptic bronchoscopy and BAL in asthmatics. Summary and recommendations. Am Rev Respir Dis 1985;132:180-2.

23 Djukanovic R, Wilson J, Lai C, Holgate ST, Howarth PH. The safety aspects of fibreoptic bronchoscopy, bronchoalveolar lavage and endobronchial biopsy in asthma. $\mathrm{Am}$ Rev Respir Dis 1990;143:772-7.

24 Worden KA, Metzger WJ, Kopp W, Richerson HB, Hunningshake GW. Dissolution of eosinophil granules in bronchial lavage obtained from allergic asthmatics during bronchoprovocation and seasonal exposure. Proceedings of the Electron Microscopy Society of America 1983;41:798801.

25 McDowell EM, Beals T. Biopsy pathology of the bronchus. London: Chapman and Hall, 1986:55-73.

26 Montefort S. The role of adhesion in inflammatory airway disease. $\mathrm{PhD}$ transfer thesis, University of Southampton, 1991.

27 Evans MJ, Shami SG, Cabral-Anderson LG, Dekker MP. Role of non-ciliated cells in renewal of the bronchial epithelium of rats exposed to $\mathrm{NO}_{2}$. Am J Pathol 1986; 1213:126-33.

28 Frigas E, Gleich GJ. The eosinophil and the pathophysiology of asthma. J Allergy Clin Immun 1986;77: 527-3. 